\title{
Education Functions and Knowledge: Philosophy in Islam
}

\author{
Abdulaziz Omar A. Jughaiman, \\ King Saud University, Saudi Arabia
}

Doi:10.19044/esj.2020.v16n5p120～ＵRL:http://dx.doi.org/10.19044/esj.2020.v16n5p120

\begin{abstract}
This paper focuses on exploring the functions of education and the concept of knowledge in Islam. The importance of human intelligence compared to artificial intelligence and the importance of language in education is also discussed. This paper further examined phenomena, true concepts, the concepts of ideology and suggested definitions. It used Quran verses, measurements, and deduction methods along with morphological, semantic, and grammar analysis. It also used philosophical interpretations, scientific discoveries, logical values, and symbols such as if-then-or-and-no. This paper discovered that the function of education in Islam takes the environment into consideration. It depends on reward and punishment, and upon the principle of what is harmful and what is not. It entails the setting up to gain the confidence necessary for education in addition to other fundamental educational functions such as repetition, orderliness, accomplishment, manners of consumption and aesthetics appreciation, etc. The study also highlighted the importance of using competent language and honest artificial intelligence in education. It further discovered that Islam encourages scientific curriculum and accepts scientific explanations for general descriptions. It was suggested that Islam should require an electoral process for imam or teacher and ethical materials within the curriculum. This paper is of the opinion that knowledge is an interpretation, and the search for it is endless, while visions are phenomena. This paper therefore suggests explanations and definitions for many important concepts that will contribute to a better understanding of many phenomena in education, ethics, language, and artificial intelligence.
\end{abstract}

Keywords: Philosophy, Education, Religion, Language, Artificial Intelligence

\section{Introduction}

Islam, since inception, has always had a message that calls for knowledge and encourages learning to combat ignorance. Down the line, this 
message transformed into what is now known as Islamic civilization, which has made a lot of scientific achievements. Faith in God is fundamental in Islam because it is seen as faith in human spirit and human rights. This serves as the moral values that enable humans to survive, feel, accept, and produce the literature, arts, and beauty. Furthermore, it also helps to create a sense and an expression of love within a wide range of faith while science remains partial, variable, and specified by the scientific theory, experiment, and mathematical proofs. The emergence of the Islamic religion is associated with the mission of the prophet Muhammad, in the same way other Abrahamic religions are associated with prophets Jesus and Moses. Prophets are humans sent with miracles in accordance with ethical standards to all nations at different periods of history. Therefore, their aim is to form a moral revolution and righteousness. Their effect has expanded over the world which has earned them a global adjective. While philosophers and scientists are humans known through their compositions and discoveries to reach all nations, there are common denominators between them and the prophets. These denominators are the ethical commitment. In addition, they all urged knowledge and the fight against ignorance, and they also experienced all forms of oppression. The differences are in terms of the miracles and sanctity for prophets and the approach that are subjected to the level and size of their faith and acceptance.

However, philosophers are non-traditional thinkers besides their scientific objectives that are subjected to experiments. Thus, this paper defines educational functions as behaviors, ethics, objectives and ideas that enable humans to learn effectively. Also, it interferes in determining appropriate means and their uses. It defines education as building the mind, i.e., cognitive and ethics of humans that enable them to survive and achieve more choices. This paper uses these definitions with a simple logical method and presents a brief definition of many concepts.

\section{The Functions of Islam Religion in Education}

"Al-Alaq; read (prophet Muhammad) in the name of your lord who created. Read! Your lord is the most generous, who taught by the pen. Taught the human what he did not know" (Shaykh, Shaykh \& Darwish, 2009). The philosophy of religion is the study of religion in its essence by examining the functions of religion between humans function in a society. Also, it provides, "if necessary", a criticism for all of these (Peter Kunzmann et al., 1991). The functions of education in Islam begin with the teachings of worship which is the second component in Islam. Hence, it is not restricted to mosques where Islam teaches purity and reading by offering prayers. Islam also emphasizes on food teachings, where Muslims offer sacrifice in pilgrimage. Here, Islamic teachings of animal killing involve slaying the animal as an organic killing way, like the hunting way, to ask for mercy. Therefore, the animal does not go 
through death case, it immediately turns into edible meat. As a result of this, eating dead animals is forbidden in Islam because organisms that eat carrion (dead animals) are often at the end of the food pyramid. Just like Prophet Abraham, the aim was to enact the sacrifice and not to slaughter his son. AsSaffat; "so, we ransomed him with a mighty sacrifice" (Shaykh et al., 2009).

Fish and other sea-food are like fruits that remain fresh until they are picked. Al-Nahl; "it is he who has subjected the sea to you, so that you eat of its soft flesh." Al-Ma'idah; "you are forbidden to consume the dead, blood, and the flesh of swine. Also, flesh dedicated to any other than Allah, the flesh of strangled animals, and those beaten or killed by falling, gored to death, and mangled by beasts of prey. Unless you find it still alive and slaughter it. Also, animals sacrificed on stones to idols. You are forbidden to seek division by the arrows, that is debauchery. As for he who does not intend to commit a sin but is constrained by hunger to eat of what is forbidden, then surely Allah is forgiving and merciful" (Shaykh et al., 2009). Also, it is not only because the dead is not for human beings, but also because it is for some animals that feed on carrion. Thus, Islam takes into consideration nature and the organisms that participate in nature. The exclusion here is when the animal is slaughtered before it dies as a kind of mercy for the animal against torment to death, as well as the type of food resource management in an optimal way. Also, if the dedication was to someone other than God, then it has a metaphysical power with corrupt or unjust intentions. Here, a kind of polytheism is practiced (Jughaiman, 2019). This involves sorcerers who require animals slaughtering for dirty targets in an ugly way, like sprinkling of blood. In addition, an animal should not be hired, like renting for milking or mating, because it may harm the environment and the owner. This applies to humans as well since it is not permissible to rent or sell any part of the human body.

At-Talaq; "if they suckle, give them their wage and consult together honorably. But if you both make difficulties, let another woman suckle for him" (Shaykh et al., 2009). Here, wage refers to earning custody and nurture, not for milk or breast. Therefore, a relationship arises from breastfeeding: mother, brother, and sister and this gives the role of education a spiritual meaning. Also, this verse "constrained by hunger to eat of what is forbidden" is a function of education that differentiates between need and necessity.

While human necessity is impermanent, human need is permanent. Therefore, searching for freedom is permanent and looking for life is also permanent. Hence, paradise means permanent life. In addition, the Quran's call to thinking is like considering the universe and its component. Here, an essential part of the educational process for the purposes of faith is to be ethically disciplined. It is important to know how to think before starting to think, because material targets may lead to the use of illegal or inhumane means. Likewise, the search for knowledge is endless, not just to achieve the 
physical goal. Here are three elements: target, mean, and outputs. The mean is consumed to reach the target, and this result in outputs. Therefore, the outcomes of education are affected by the nature of mean and target. Belief in God means faith in life and survival. A person who seeks to make money strives to achieve a target of survival and freedom. This is why paradise was associated with hereafter because it is a permanent life with absolute freedom, where the believer gets everything. On one hand, justice is a righteous deed, and in the same way planting a tree is a righteous deed. On the other hand, injustice, cutting a tree, stealing, killing, and cheating or lying are unrighteous deeds. The philosophy of permissible and forbidden in Islam depends on the principle of what is harmful and what is not, whether on the personal level, the environment or other levels. This educational function in Islam depends on reward and punishment as a result of deeds. Consequently, the worship that does not achieve a righteous deed is not worship but hypocrisy or just an empty ritual (Jughaiman, 2019). The worship takes the form of circling in praise, in prayer, or around the Kaaba. This happens as time circles every time, every day, every week, every year, and during one's life-time. It starts from a season, time or place and returns to it again. Using the moon for the count, which starts its time from the evening, there is a link between this system and the descriptive system of the universe in the Quran and its components that praise god. Here, the system is defined as the process that does not cause problems or malfunction and everyone can get along with it. In Arabic language, a word of swimming means finishing the distance, i.e., going and returning back. More so, it is not said for the person that he is good at swimming until he finishing the distance. Ya-Sin; "the sun shall not outstrip the moon, nor shall the night outstrip the day. Each is floating in an orbit." Al-Esra; "the seven heavens, the earth, and whosoever in them, exalt him. There is nothing that does not exalt with his praise, but you do not understand their exaltation" (Shaykh et al., 2009). At this point, repetition, orderliness, and accomplishments are educational functions. Also, in Islam, there are teachings of non-duty acts which have become a part of customs and tradition (Jughaiman, 2019). There are certain acts that reward their performer and do not punish those who leave them. Conversely, there are also acts that reward those who leave them and do not punish their performer. Thus, the function of education here depends on the reward only. This is in addition to sincerity which is the honest will in worship and business, and this is the opposite of betrayal or fraud. As a result, the malicious intents may hurt. Here, there is a kind of spiritual education that paves way for honesty. This means that humans learn sincerity if there is no need to lie. Also, the basic principle in humans is that they are honest, unless proven otherwise. This gives the minimum confidence necessary to remove the general suspicion or lack of confidence, which may cause a psychological infection in the society as the phobia. In this 
case, caution will not threaten confidence. Furthermore, worship is mentioned in the Quran. Adh-Dhariyat; "I have only created jinn and men, that they may serve me, no sustenance do I require of them, nor do I require that they should feed me'" (Shaykh et al., 2009). This expresses the relationship with god. "Serve" here is not in the sense of slavery, but in the sense of worship that brings to human what he is looking for, by the meanings found in the names of God, because such a relationship is based on the honouring of God to humans. Also, humans were not created to run forced labour such as the practice of slavery. The relationship with God also links to the reason for the human entity. In Islam, God has ninety-nine names, which are used in an Arabic naming way with the combination Abdul-name. No prophet carries one of these combinations of names. However, there are a lot of leading and influential Arabic personages in their communities before Islam, who had combination of names. In addition, those personages have not been subject to slavery but they have a lot of slaves. Therefore, those personages by these combinations of names are eager for that relationship with meanings such as dignity and pride. In addition, a worship word is derived from loyalty. This word expresses the most beautiful meanings of ultimate love and faith, i.e., love of life and faith in life. It is pure love without human instincts that are associated with the relationship of humans with humans. It is also consistent with human capabilities through performed prayers and supplications.

Furthermore, it does not require any practices of self-flagellation or any painful behaviours for the body or soul that search in spiritual integration in the love of God. This faith gives trust as a kind of spiritual trust that helps human overcome all forms of frustrations resulting from failure or injustice of life in all his affairs. At the same time, it is not a kind of laziness, as God would bring him whatever he wants without having to try. Fatir; "no laden soul shall bear another's load"' (Shaykh et al., 2009). Here, man is responsible for what he does as an educational function that teaches responsibility (Jughaiman, 2019). The nature of the human soul owns its feelings of fear and aggression that needs faith that works to control it. This means that faith is a spiritual value that makes a charitable force dominant over all powers. Its moral value gives a level of fear to help in preventing any kind of oppression against others.

Also, it gives the level of tranquility to deal with the rest of human beings and other beings with confidence especially metaphysical beings like jinn. Its faith holds the adjective of hope. However, this hope is inexhaustible in achieving what human wishes despite the difficulties. Therefore, a preparation to gain the confidence necessary for education is an educational function. According to Dr. Goleman "The creativity comes from the inner essence of human and if this human lacks trust and hope, the task of educating a child can become a difficult task" ( Pfenninger, ShuBik \& Bahboh, 2003). 


\section{Language, Human, and Artificial Intelligence}

Theology, which literally means "science of discourse", in Islam is a purely mental debate about theological concepts (Al-Mūsawi, 1989). One cannot talk about the computer, until it is manufactured. Thus, the word "computer" is used as a result of the creation of computer. Also, the name "computer" refers to the computer idea before the idea is manufactured. The idea is a volition which is the result of a thought process that preceded the name of the computer. As a result, some words are deleted when a wrong meaning is discovered. This leads to talk about the prophet Muhammad who was not an inventor. Also, the Quran, as words of Allah (the creator), is not a creature but a revelation because when the adjective is the creature then the described also will be a creature. Yusuf; "we have sent it down, an Arabic Quran, in order that you understand" (Shayk et al., 2009). Revelation in the Arabic language has a conjugation with the verb of landing. The landing here is not in the sense of landing rain, where humans at that time did not realize the scientific fact of it as a process resulting partly from the evaporation of seawater. The Quran mentions the role of the wind in the rain-fall. The landing means moving from a higher place to a lower place. Furthermore, the landing has a conjugation by mercy and blessing vocabularies. However, the prophet Muhammad was not the maker of that news because it talks about the creator, the creatures, the causes, and results. This news is not ideas but it causes one to think. Subsequently, the ideas can be invented in the mind of a person when he is absorbed by specific knowledge. As-Saff; "and when prophet Jesus, the son of Mary said: and to give news of a messenger prophet Muhammad who will come after me whose name shall be Ahmad" (Shaykh et al., 2009).

In Arabic language, the names of people can be derived from verbs. Ahmad is a name derived from the verb "to praise", and Muhammad is a name derived from the adjective "praise". When the verb turns to an adjective, the verb does not turn into another verb. This means the end of that verb. Subsequently, it is said, "the man is planting the land". Later it is said, "this land is a planted land". The verb "planting" is ending, and it becomes an adjective for the land. Therefore, the verb "Ahmad" is ending, and it becomes an adjective for Muhammad. The names of God are the most beautiful names which are permanent names that do not die or discontinue. In addition, these names may be carried by humans which should not result in wrong comparison. This is because the creator comes before the creature, in the same way the name comes before the adjective. As such, we cannot use "humanity" before making use of "human". Also, there is no word in the language used by humans that has carried no meaning. Al-Baqarah; "he taught Adam all the names of everything, then he showed them to the angels and said, "he taught Adam, father of humans, the names of all of them and then presented them to the angels, saying: tell me the names of these, if you are truthful" (Shaykh et 
al., 2009). The importance of language and word is that they express objects from the largest part to the smallest part. They also create logical links when used, especially if those objects were named by their creator. Thus, the language used in computer programming is a result that enters into the machine to execute what humans want. "The process of preparing a program for a digital computer is especially attractive, not only because it can be economically and scientifically rewarding, but also because it can be an aesthetic experience much like composing poetry or music. These machines have no common sense, they do exactly as they are told, no more and no less (Knuth, 1997). The Quran is a linguistic miracle because it gave a true result in perfect language. If a human was able to choose through the machine, he is unable to choose except based on mathematical logic and the individual programmer's desires. In addition, if the senses have taught humans sometimes about what they choose, then the sensors that translate by a machine into a number, color, or movement makes the right and necessary role of the machine as a complement to humans' ability. Otherwise, humans will choose to deal with the machine not deal with the human.

Human Ability Not Machine Ability

\begin{tabular}{|c|c|c|c|c|}
\hline Human Ability & $=$ & Human Ability & + & Machine \\
\hline Machine & $\neq$ & Human & + & Machine \\
\hline Machine & $\neq$ & Human & & \\
\hline Source: Author & & & \\
\hline
\end{tabular}

Equation 1: This is the necessary limit for a human to not turn into machine

One of the skills of computer programming depends on the ability to express something in a particular language. The danger is if the spoken human language is misrepresented or relapsed. Relapse of the language or linguistic intoxication is the mention of the name or adjective for another meaning. For example, using the phrase "God so and so" is a poisoning of the name of God renamed. It is to exchange meaning to another name that requires certain restrictions. "So and so" requires a criterion to fulfill the desires of those who believe in him. Those restrictions are political and social which confiscate the individual's freedom. This applies to food poisoning when exchanging the name in another meaning as seen in Table 1 below.

\begin{tabular}{|c|c|c|c|}
\hline \multicolumn{4}{|c|}{ Linguistic Intoxication } \\
\hline The Renamed & 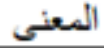 & Name & الانسم \\
\hline Mourned (Died) & نعي & Mint & نعناع \\
\hline Fall & سقوّط & Beans & فول \\
\hline Deceit & مكر & Pasta & ماكرونة \\
\hline Source: The Author & & & \\
\hline
\end{tabular}

Table 1. Language poisoning by using names with different meanings 
Arabic poetry is full of coding due to political and social reasons, just like artificial intelligence, which was mainly for the protection of information. However, the danger is if humans may need biological encryption to protect their privacy. Also, encryption sometimes is a means of crime that thieves use to hide their identity. In addition, if some words or pictures are prescribed in the machine's memory, it will not imagine them. Nevertheless it will express it in another language with a speed that may not be compatible with the human feeling or a secure humanistic psyche. Thus, imagination is one of the secrets of a human genius. The imagination that characterizes humans is a form of vision according to the choice of human, but it differs from the dream which is influenced by a lot of randomness in an unconscious case.

At this point, the choice is affected by many psychological variables. Sometimes, the choice will not be always true. Al-Jinn; "but there were certain men from mankind who would take refuge with certain males from the jinn and they increased them in tyranny" (Shaykh et al., 2009). The jinn have increased them with fear inherent with wrongful actions such as fear inherent with murder or theft like drug users when crime is perpetrated. Fear disrupts the ability to think logically and disrupts self-confidence as well. The fear reaction is like wild animal reaction; escape or brutality. Humans are intelligent and sociable (ESTENAS as an adjective derived from ENS). Nevertheless, the jinn in the language is the opposite of tranquility and are intelligent. In the language, it refers to losing calmness or anger, any acceleration of thinking, movement, words, and violence, or brought something unusual (JUNON as an adjective derived from JINN).

Therefore, any nervous condition when photographed or measured may results to something comparable to the imagined picture about the jinn. Also, angels are creatures that do not tranquil on earth. Al-Esra; "had there been angels walking at peace in the earth" (Shaykh et al., 2009). The difference between the angels and the jinn or mankind is that the angels are completely obedient to God. The world of jinn and mankind is a world where there is a lot of sin, instincts, and narcissism. As in the story of Adam's sons, Al-Ma'idah; "then Allah sent down a crow, which dug the earth to show him how to bury the naked corpse of his brother" (Shaykh et al., 2009). At the same time, it was a kind of education that educates the human on how to bury the dead and to wear a black dress, as the color of the black crow.

The vocabulary mentioned in the Quran is not all the vocabulary used by Arabs in poetry or literature, but it is the most beautiful and accurate Arabic vocabulary. Hence, language is of significant importance in education which can be likened to the software humans use naturally. This applies to the rest of the international languages. If it was not a beautiful language, it would not have survived and would not have become a means of learning. In addition, the modern vocabularies that resulted from industrial revolutions, such as 
computers, should not be Arabized. However, they should be used as named by their inventors.

\section{Discussion}

What is a miracle? A human or robot? Is it a miracle for the first human to see the scientific progress made by today's humans? Or does today's human consider the creation of the first human as a miracle (natural intelligence, artificial intelligence or human hybrid)? The genius human had invented the calculator for his needs for accuracy and speed. This is not same with the human who used a means that allows him calculate mentally as the calculator machines such as hybrid or cheater. However, the fundamental need is for a human that is able to invent rather than humans that are able to calculate. The ability to calculate mentally as natural ability is important for memory stimulation. Howeve, it should not be an educational target. At the same time, excessive use of technology affects education as it stimulates senses more than thinking or writing. This is because it is a direct reception filled with pictures and movement that reduces the brain's ability to natural imaginations.

Therefore, the animal can remember but cannot think and reacts only through its senses. Knowledge is not for consumption and if consumed, it turns into an ideology and this happens only through commercial or political propaganda. This shows the significant importance of the educational method and judgment. Al-Furqan; "who when they spend are neither wasteful nor miserly" (Shaykh et al., 2009). The education function here is related to consuming what should be oriented. Wasteful and miserly are the limit that makes spending behavior harmful. Also, charities should not carry business or political names as propaganda this is to be human and to not consume good.

The innocence of children cannot endure the malice related to politics, and they cannot understand sex as it is only for adults. There is a need for artificial intelligence to produce the machine that serves humans. The need should not be directed to produce a hybrid human that serves machine by means like narcotics, some electric or charlatan interventions which may be the same means used in psychological rape or psychological seduction. The vision is part of the prophets' prophecy, and this does not apply to nonprophets. All miracles occur upon a direct intervention of a capacity that is not possessed by a human. It is an event that comes to prove the truth of Quran or scripture, because it surpasses the output of science at the time, even in the long run. At the same time, "sciences or scientific conclusions are usually infinity and subjected to reviews when the new proof is discovered.

Therefore, religious beliefs based on scientific discoveries provide religion with shaky support. Miracles, on the other hand, cannot be explained scientifically or it will not be a miracle. In general, miracles are not repeated, while scientific phenomena are frequent (Spielberg, Anderson \& Johur, 2002). 
This should not be used by human to propagate a crime, such as direct radio broadcasts or electronic messages that penetrate the mind. It is a kind of perfect crime imputed to god falsely. This produce a dangerous type of reading known as a memory reading in the form of images by which the sleeper reads the dream through his active memory only. For example, when directing a question to someone, before he answers, he will think, he will, sometimes, remember, and he will open his mind. In this case, if there is a way to read what is going on in his imagination, this can be interpreted or translated using electromagnetic waves. Thus, this will reveal what is going on in his mind, even if he refuses to answer. In addition to the yes or no directed questions, to read its answers by changing of impressions. Furthermore, this creates a problem, if the technology or artificial intelligence is used dishonestly.

Are dreams a form of knowledge? Do the dead return only through memory? One of the meanings of the picture is the illusions of the facial features. Photography sometimes evokes the absence, whether alive or dead, despite his physical absence. When someone perceives a smell during his sleep, he just remembered a smell. The three dreams story of René Descartes according to historians, and the criticism that followed, that his philosophy was based on dreams is unjustified, because these dreams has not been scientifically proven and cannot be subjected to witness. It was not recited in a bible, and he is also not a prophet. If this is true, it will be as a faculty, a genuine faith, or perhaps it was a means of persuasion and popularity in an era that believed in metaphysics more than science to make a cultural revolution.

The dream has a greater impact than the influence of reality on the cognitive senses, especially dread without the full power to deal with. For the sleeper who sees a lean cow eating a fat cow, his vision will be great, scary, and would occupy his thinking. Thus, it is a kind of exaggeration because the sleeper though unconscious is aware through his imagination. What he sees will totally or partially be vague and unrealistic like a cow eating another cow. In fact, if the dream is true, its significance is usually very little and sometimes trivial. However, this is just like the poet or the artist (sometimes) in his poems or works of art, especially when he uses exaggerations. The vision (if it was natural) comes as shorthand because the mind translates it as pictures. Also, the mind often translates words into images, but it does not come encrypted. Repressed emotions or repressed instincts have a role in shaping it. If someone lose something in an inattention state, his memory recorded all details. And if he sees a vision to find it. The interpreter may have explained the memory that was shorthand or mixed. The other possibilities remain metaphysical, and this metaphysics, sometimes, is a healthy phenomenon for human tranquility.

This is because humans cannot always accept the future. The interpretation of dreams was part of Joseph's prophecy. So, other dream interpretations are like the palmistry. Yusuf; "Joseph, the truthful, tell us of 
the seven fatted cows that were devoured by seven lean ones also of the seven green ears of corn and the other seven which were withered. He replied: you shall sow for seven years as is your way. Leave in the ear (of corn) you reap, except a little which you eat. Thereafter, seven hard years will come upon you which will consume all but little of that which you have stored.

Then, there will come a year in which people are helped, in which the people will press" (Shaykh et al., 2009). A fat cow indicates a lot of grass which in turn indicates a lot of rain. Lean cow indicates a lack of grasses which in turn indicates a lack of rain. Seven indicate greatness and perfection. The year, the month, the day, and the night may be incomplete, but the week is not less than seven days. Also, the number of heavens and earth in the Qur'an are seven. Also, it carries more depth as corn is grown and then harvested.

Thus, a year of planting corresponds to a year of harvest. Therefore, he said, "leave in the ear (of corn) you reap" and did not say extracting from the ear (of corn) and then stored. So, here is an idea of strategic storage, which includes storing corn in the ear (of corn). This is because extracting requires more efforts and more pay in an emergency case. Being hardly enough to feed means a reduction in consumption. Also, reducing the cost and efforts, as well as the quality of the storage is free of containers that require more industry which in turn means more cost as shown in Table 2.

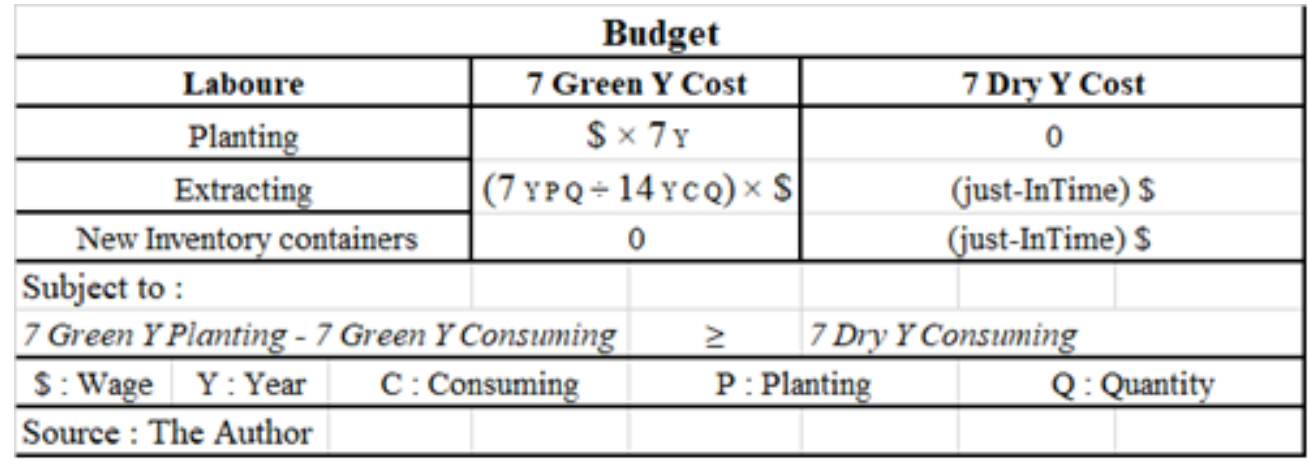

Table 2. Strategic Inventory, Zero Inventory, Cost Minimization, and Reducing the consumption of a Commodity when expecting a shortage of supplies.

Here is an application of just-in-time philosophy "which for excellence (indeed, perfection). Just-in-time is frequently used interchangeably with "zero inventory" and "stockless production but it represents a production strategy and not just an inventory control technique. It identifies a philosophical pursuit or set of goals that apply to any type of production organization in the broadest sense. Its aim is the elimination of all waste and consistent improvement of productivity" (Tersine, 1988).

So, the difference between the king and prophet Joseph is that the one who saw the vision is the king, and the one who interpreted it was the prophet, Joseph. So, the prophecy here is Joseph's interpretation and not the king's 
vision. Yusuf; "one of them said: I saw (in a vision) that I was pressing grapes. And the other said: I saw (in a vision) that I was carrying bread upon my head, and that birds ate of it. Tell us its interpretation. My fellowprisoners, one of you will pour wine for his lord whereas the other will be crucified, and birds will peck at his head" (Shaykh et al., 2009).

Bread is a metaphor for a livelihood because bread is a food for all people, rich and poor. "Carries over the head" means a judgment day. A bird eating from his head means a penalty and after carrying bread, he no longer carried anything. Here, humans learn to spread wheat grains for birds as a kind of search for peace. This is in addition to the method of making bread, which depends on leaving it in an open air until it is acted upon by bacteria. It is also a metaphor to be crucified naked. Here, the moral value of the importance of how to earn a living is legitimate! Or at the expense of the others gains (prohibited)! Furthermore, wine means pleasure or sympathy for forgetting penalty in addition to pardons. Youssef represents an example of the importance of honesty with the soul in the advancement of man to a high level of ethics as well as knowledge.

Therefore, honesty is one of the most important qualities of the prophets alongside with knowledge. Honest people oftentimes results to an honest society. The function here is that knowledge is an interpretation while visions are phenomenon influenced by personal characteristics, environment, culture, and scientific progress.

\section{Knowledge in Islam and Scientific Facts}

The theory of knowledge and science is related to the nature of knowledge and its limits. One of its themes is the relationship between the self-knowledgeable, subject, and content. The theory of science deals with the hypotheses and the fundamentals that are necessary for each science. It also deals with scientific approach, its fundamentals, its concepts, and its objectives from two angles: first is to clarify it and, second, subject it to a critical study (Kunzmann et al., 1991).

Subsequently, knowledge is the faculty that enables human to obtain science. So, mathematics science is achieved by the knowledge of mathematics. In addition, the intellectual man is the man who has knowledge in manifold sciences. The Quran refers to some of the universe components, creatures, and the abilities of god, in the form of verses. Al-Anbiya; "that the heavens and the earth were sewn up as one (solid) mass, then we unstitched them, and that we made every living thing of water? Will they not believe!" (Shaykh et al., 2009). A verse in language carries the meaning of miracle, grace, or torment. For example, An-Naml; "you will see the mountains which you think to be firm pass by like clouds. (Such is the) making of Allah, who has created everything well" (Shaykh et al., 2009). However, it is not to say 
that it is indicative of the rotation of the earth but urges one to think about the reality of the movement of land and mountains or its stability.

Also, that is a beautiful description of a precision done. On the other hand, the misunderstanding or misinterpretation of the Quran makes it vulnerable to deformation. At the same time, the scientific facts that man has discovered and proven are facts that encourage the ratification in the Quran as a call to faith. The Quran does not provide these verses in the context of scientific or academic research. However, it provides verses in the form of questions such as kind of answers that urges the mind to research and think away from the accumulated ideology by using sentences such as "if they know" and "do you understand" in reference to science and reasoning. James Thopper says, "it is better to know some questions than to know all the answers" (Harold \& Al-Ayoubi, 2001). Consequently, the Quran description is accepting any scientific attempt to explain or prove the general description of a certain fact. At the same time, the Quran is not subjected to science.

This description that came in general is simplified, and it is a beautiful language that makes people who believes in the Quran to believe in science. Ta-Ha; but say, "lord, increase me in knowledge" (Shaykh et al., 2009). Man believes in the existence of the sun and the moon, but he does not have a full knowledge about them. At the same time, he has the knowledge that made him realize that there are laws. The role of the sun and moon is proof that they function according to law. Therefore, human should not fall into the dilemma of any contradiction of science with religion, else the Quran could not address people and attract them at all levels of culture. In addition, over successive historical periods, human was able to accumulate many scientific discoveries.

Therefore, there is an increasing amazement in the Quran whenever there is a new scientific discovery or truth through several features: the increase in immenseness and divergence of science, the majesty quality, and the general aesthetics quality of description in the Quran. Therefore, it is not possible to separate the faith approach of the Quran and the scientific method in order to make a comparison work. This is because the first approach is a motivation for the second approach. In addition, the Quran uses 'news style and times'. News informs about the state of an object or event in the past, present, or future. On the other hand, time carries changeable concepts across knowledge history. "The concept of Einstein's for place indicates the place of a topological quality for the world of material objects, and Newton's concept of the material things that exist only in the place shows that a material thing can only be understood as much as what is in the place" (Balibar \& Addhum, 1993).

Let say time is what appears to be the place of the place. The universe is stretching, and the time is stretching. The place changes when any piece of material is made up, to start its effect as history events have its time and its 
place. Here the history calendar represents time or the place. The clock is only a means of measuring time in space-time.

\section{Discussion}

Let us express date or time, by the word of place, to say it happened in the place of the prophet Muhammad, happened in place of the prophet Jesus, or happened in the place of philosopher Socrates. This will bring out the traditional concept of time. Figure 1 shows some beings with different features, four different dates and one action.

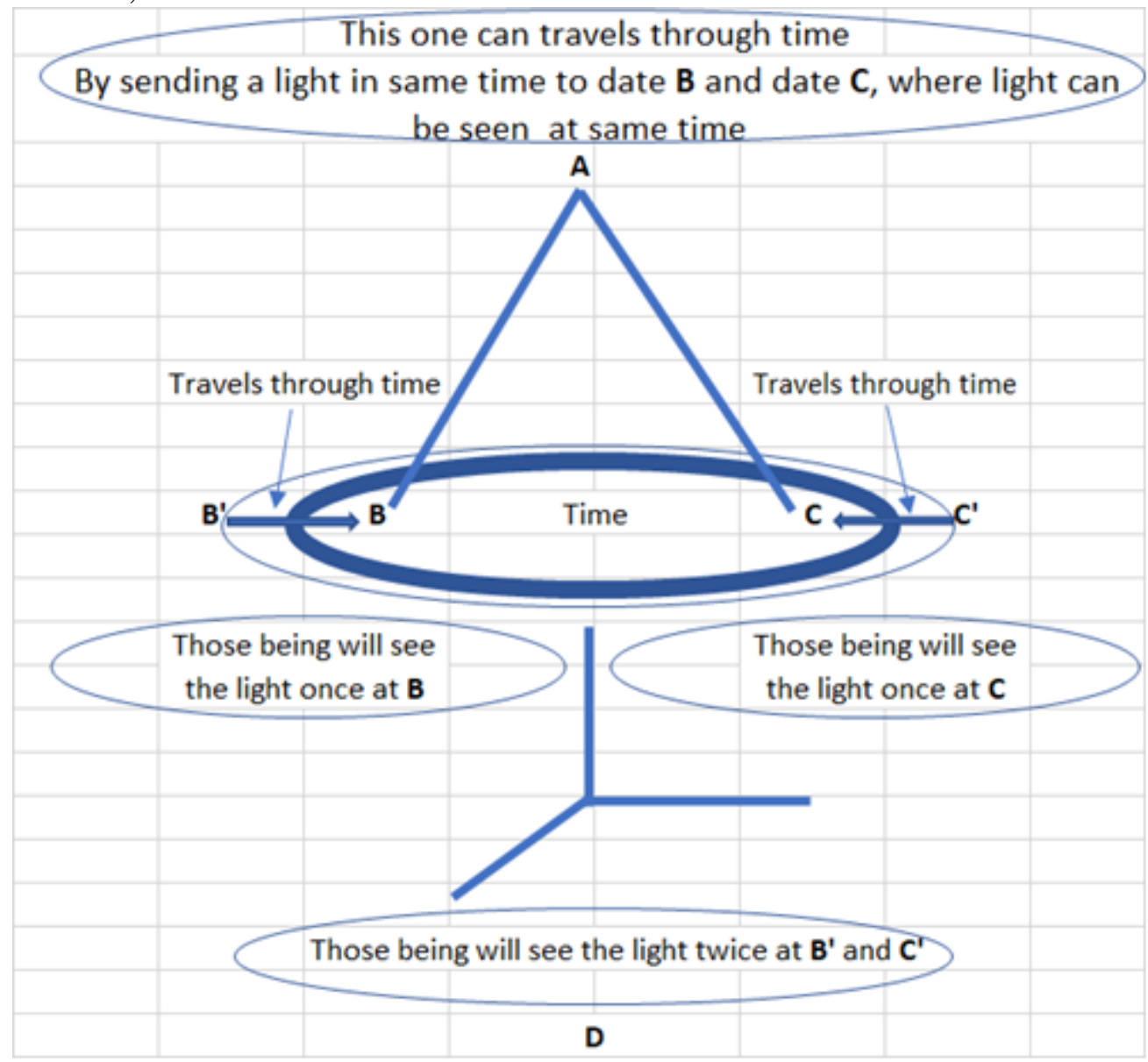

Figure 1. When starting light from the point $A$ in time $A$, it can be seen at point $B$ in time (date) B, B', and at point C in time (date) C, $C^{\prime}$. So who travels at the speed of light will see it at $B, C$ instead of $B^{\prime}, C^{\prime}$ by traveling through time from $B^{\prime}$ to $B$ and from $C^{\prime}$ to $C$.

Source: The Author.

"Einstein says that all objects in the universe are always moving through space and time at a constant speed, it is the speed of light. The moving object in the place, at the speed of light, has no any remaining speed for it to move through time, which means that light never ages, and objects that move 
at the speed of light do not acknowledge the passage of time" (Greene, Mansoor \& Shimon, 2005). Human is aware of his memory contents, the interactions of that contents, and all the secrets associated with it.

As if knowledge is a form of creation, because knowledge is prior to the creation process, this does not offer human memory a kind of induction to not generalize the part on all but provided one of the human abilities that explain a form of knowledge. Furthermore, he can navigate through his memory in the past and future. Man possesses the ability to acquire knowledge which enables him to probe the universe and discover more planets and microorganisms. Therefore, his ability is not in his size. Al-Hajj; "if a fly robs them of anything, they could never rescue it from it. The seeker and the sought are alike in their weakness" (Shaykh et al., 2009). Humans are relatively weak with flies, although they are much larger in size. Despite the recent progress of science and nanotechnology, human outside the laboratory in his environment is unable to save or recover what flies have taken. On the other hand, for an object smaller than a fly, it is irrecoverable to its original condition. Therefore, the perception of the objects by the naked eye makes consciousness a part of human life. It helps him to make a difference between what he sees and what he cannot see, what he hears and what he cannot hear.

Therefore, human does not like to eat food with the eyes of a fly or another object's eyes. In addition, to see beauty only by his eyes and, hear what he likes to hear by his ears. At the same time, he is not the size of the earth or the mountains. Al-Esra; "do not walk proudly in the earth. Indeed, you will never tear open the earth, nor attain the height of mountains." Lugman; "walk modestly and lower your voice; the most hideous of voices is the braying of the donkey" (Shaykh et al., 2009). Here, it also entails a deterrent moral to limits the arrogance of human over human, or over the environment, as well as the importance of public taste and vocal tasting. "The scientist can describe to you the sound vibrations in terms of physical properties and the response of auditory nerves to it. As soon as he is over, he will be depleted as a physicist.

As a human being, he will not be convinced that he has touched any aspect of the beauty of music. This aspect needs another kind of coexistence or living. Thus, it seems detestable that the music is described as just vibrations imposed on static air molecules (Polkinghorne \& Ali, 1998). The role of music in education is not limited to being merely an educational subject, but rather as a complementary subject that gives a kind of mental harmony. Islamic curricula are limited to canticles. Religious scholars differ based on the authenticity of the hadith that prohibits the musical instruments and the explanation of Qur'an. Lugman; "there are some people who would purchase distracting talk, to lead astray from the path of Allah without knowledge and take it as mockery" (Shaykh et al., 2009). The explanation here is: purchasing means a fateful choice versus the opposite. And if it is considered that the 
meaning of the distracting talk is songs, it may or may not be accompanied by music. Hence, this depends on the content of the songs. This is also conditional if it is going astray from the path of Allah, the way of believing in God, and faith in listening and reading the Qur'an. Therefore, this is also applied to commerce. Al-Jumu' ah; "yet when they see some commerce or amusement, they flock to it" (Shaykh et al., 2009). Therefore, when reciting the Qur'an in a prayer at a time when music or singing is performed, the Muslim is committed to choose the Qur'an. He takes into consideration reciting the Qur'an in mosques from the beginning to the end, and not just only reading selected verses so that the Qur'an is not used in political propaganda (Jughaiman, 2019). Music is the tune of emotions that express every psychological case from joy to sadness and paints the dimension of the human emotions. It is evoking the human tendency to romantic temper that helps in emotional liberation, instead of preoccupation in temper of satisfying instincts.

This leads to talks about the aesthetics philosophy. So, what is the main influence in the determination process of aesthetic value? Is it emotion or instinct? Instinct is a motive of necessity, whereas emotion is a motive of needs. Emotion helps to determine aesthetic value. So, "the aesthetics are relating to the definition of beauty, in general, and the forms of its appearance in the arts and in nature and to determine his impact on the recipient. The aesthetics are not associated with their subject, except functionally, whether as a description or evaluation. Along with putting theory in the arts, aesthetics also is dealing with aesthetic judgment issues, forms of aesthetic feeling, and aesthetic issues that coexist. In modern aesthetics also, there are topics related to the theory of the media and topics related to linguistic analysis" (Kunzmann et al., 1991). The sense of beauty begins with everything that the eye falls on.

The feeling of it varies from person to person depending on the environment and cultural conditions. Colors have a reflection on understanding, culture, and the relationship with nature. In Arab culture, the brown woman is a woman with black hair or black eyes. The blue and yellow color gives a kind of contrast and expresses a sense of jealousy just like the contrast between the sea and the desert. Fatir; "did you not see how Allah sends down water from the sky and with it brings forth different colored fruits? In the mountains there are paths of various colors, of white and red, and jetblack" (Shaykh et al., 2009). Beauty tasting is an important educational function, and the precious cultural and artistic legacy was one of its results.

The emotions of humans represent a form of body language that reflects his constant search for each beauty. Also, it represents a form of faith in beauty and various evaluations of aesthetics. Furthermore, it leads to more daring behavior to produce aesthetics through art and literature, with a thirst to possess it, and with more careful behavior to maintain it. Human appreciation for beauty depends on everything accumulated in his memory. 
This is done through laws that are shorthand in the human mind as a kind of criterion that governs all that he receives. Artistic production is influenced by the social and political situation. In the case of war, artistic production may reflect the qualities of war such as pornography, disintegration and violent, broken and angry psychological impressions. But, is the aesthetics representing the value? Or, is the value representing the aesthetics? Value maintains the aesthetics. Also, the literary value (behavior) or the material value represents an evaluation of aesthetics. In addition, handicraft represents the fundamental of the aesthetics industry, the civilization picture, and the genius of nations that keep its aesthetics value across centuries. Consequently, human tastes the aesthetics through the written language as a description of what he feels. All this, through his experience and imagination, accepts and creates different forms of aesthetics. In addition, why is there an acceptance for ornament on some material, even if it is not gold or other dear material?

This occurs as result of missing the value that maintains the aesthetics, which in turn, leads to a kind of aesthetics consumption. The word "faith" denoting love also means acceptance. Therefore, the principle of love and acceptance is built in the human mind to accept and love any aesthetics value, as the beauty of nature. Al-Nahl; "the cattle he created for you; in them there is beauty for you when you bring them home and when you lead them to pasture" (Shaykh et al., 2009). In addition, man has an instinctive need towards a woman as a part of his spirit to live with her as a completion for his psychological composition. Man, without a woman, is incomplete. The woman represents a homeland for a man. So, the absolute female is a woman that does not resemble men. Ar-Rum; "he created for you wives from among yourselves, that you might reside with them, and has put kindness and mercy between you." Al-Nahl; "they question you about the spirit. Say: 'the spirit is from the command of my lord. Except for a little knowledge, you have been given nothing." Al-Esra; "Allah brought you out of your mothers' wombs, you know nothing, and gave you hearing, sight and hearts" (Shaykh et al., 2009).

The spirit was what God breathed into being; so the spirit was the miracle of life. The primitive human has observed the horizon and knew that the sun will shine from a place and set at another place. So, this is a kind of science. And, if taking into consideration the adaptation factor and, if excluding the so-called deception of the senses besides the learning related to the behavior, senses teach primitive humans to feel the heat of the sun and the heat of the fire to learn the benefit of it. A heart is a means to feel others and an important factor in translating will into action or patience. Feelings affect the body as repression or sadness may cause many diseases such as Alzheimer's (also caused by inappropriate drug or food). Also, the biological sensitivity, which is the first warning of infection, is a kind of indication whose response may protect against infections. 
People of high morals are more sensitive, in addition to artists and poets. However, the influence of human experience on knowledge (as intuition) and behavior is very important, especially in education. The call of Islam to faith in God as the creator is a call that takes into consideration the disparity between all beings. This is because humans represent one being with a range of ability that cannot exceed the god ability or some other being.

This expresses the abilities of a human compared to other being abilities and before the absolute ability of god. The spiritual sense to God is the need for a god. Abraham searched for god in the sun, the planets, and found no equivalent to the spiritual sense of faith in God. He could not achieve the logic of the creator who has the absolute ability, knowledge, and who is not absent. When Abraham sought God, he sought the truth, using logical questions in his argument. Abraham's faith in God was faith in science which is intangible and was a kind of absolute freedom of thought to seek the truth. This leads us to talk about logic. "Logic is the theory about the thought in terms of its regularity and the truth of its results. The classical formal logic is divided into a secondary theory (concept, judgment, and result) and a theory in the method (methods of research and demonstration). Subsequently, the modern logical studies (mathematical logic) are increasingly oriented toward more formality and more automation. It is focused on logical calculations that must be understood as a system of relationships (symbols) with what is associated with practical rules. Otherwise, it entails treating more than one system and deals with issues more than the values that deal with truth and distribute it between (true and false)" (Kunzmann et al., 1991).

\section{Discussion}

What is the logic of the crag existence? The logic of the crag, perceived by the crag existence itself, the crag physical quality, its impact on nature, and the impact of nature on it were accumulated in the human mind as knowledge. It aims to lead human to exploit the crag in different ways. It also led him to invent crane to overcome one of the crag characteristics, such as weight. So, the logic is the truth of that crag or the knowledge about that crag.

No matter how the human senses are limited, the mind is still unaware of all facts about the sunrise. Therefore, what is the logic of things existence that human does not see or realize? The scientific development that led human to discovers many intangible things. Somehow, gives the logic of this intangible existence as a condition to the existence of human. Like the living under the surface of the water which in turn taught him that there is an indispensable thing as oxygen, which led him to understand its molecular structure. This defined logic as the expression of the object, its existence, its quality, and its interaction with other existing, which is received by thinker as a true result, and its acceptance depends on the innate, and the laws 
(experience) in the thinker's mind that is built by the process of thinking and receiving, which in turn gives the true result of thinking (intuition).

And, interpreted relationships, conditions, and results in a mathematical method are called mathematical logic. This differentiates between the imaginer who thinks with logic, and the imaginer who thinks without logic as like, who holds a paper plane by his finger, while the other one holds it with his eyes. On the other hand, ideology is an incorrect linguistically, incorrect scientifically words, correct part, or incomplete. Since language represents a result, then incorrect speech gives an incorrect result, incorrect culture, and incorrect behaviors. Seeking to understand madness may lead to madness, and this also applies to some anomalies. For example: when trying to understand the logic that says $1+1$ is not equal to 2 , this result will not reflect the inputs that led to the result, and it is closer to the randomness in which several variables are affected by other variables.

There is a scientific relationship between ignorance and madness. As for the relationship between genius and madness, it is more literary relationship than it is scientific and depends on the extent of the definition of madness. Ideology is the apparent image of the truth that does not depend on substance. Its influence in the mind is stronger than the survival of the invisible substance. It is what people see in their daily life of various abstract images without searching for the truth, so they are related to the direct senses.

Also, what is the logic of god existence? It is the clue of the mystery of being or the result that tells human about his existence. Hence, human shows the result of the existence of god. Therefore, everything is a variable creature in tune with its change and its movement with the rest of the creatures. Also, all creatures cannot live alone because they will suffer. Alternatively, there is a creator responsible for all the processes of creation. Creation entails the making of the object and its components physically from the infinite. All that human has achieved or discovered helps to invent products, develop relationships and possibilities, and in controlling social, economic, and natural phenomena. Human was given the choice between believing in the existence of a god or not based on the fact that they cannot see God.

Hence, this educational function establishes logical reasoning rather than metaphysical reasoning. Also, the physiological laws that have been formed in the human mind regulated the process of physiological growth, interaction with the external environment, adaptation, and the tendency for life or survival that humans share with other creatures. It is built-in faith in the existence of God because Adam was the first human created by God. This is true if he did not receive or learn otherwise from the environment. Therefore, education and the environment play an important role. This is clear because human in their childhood, through played roles, are intervening in the formulation of mind laws by learning. This, however, is according to what his 
parents or educators desire and according to what they want, as like as they were the users.

Consequently, there is a disparity in the outputs of education by the environment. Also, laws that are responsible for the choice and learning in humans are overlapped within complex chains including the social interactions that artificial intelligence studies are still trying to know so as to create a machine to simulate a human being. The rest of the creatures are based on the limited choices, where animals are dragged behind instincts or primitiveness in interaction with the forces of nature. In addition, the laws that man uses to produce energy and achieve industrial progress are the laws of nature that vary in terms of stability. Therefore, the philosophy of knowledge in Islam depends on the belief in the existence of one God (Allah) and that all beings have faith in Allah. In addition, Islam builds on some astronomical and climatic phenomena in regard to some of the worships, such as eclipse prayer and prayers for rain. As the sun, moon and rain are a blessing from God, the main reason for drought or natural disasters is humans' unrighteous deeds.

Since knowledge is interpretation and visions are phenomena, the king's vision is a shorthand natural phenomenon. Joseph's prediction of drought provides the forecasting as a knowledge material. The inability of a human to accurately predict certain phenomena would make him refer to these phenomena as random events and chaos. The theory of probabilities was used to test hypotheses and to determine the correct choices. Also, the science of chaos aims to construct models that simulate it. "The chaos creates problems that challenge the prevailing work methods of science because it emphasizes the complex cosmic nature. The early theorists of the chaos who send up this major by common features all of them were interested in the pattern. This is especially the pattern which looks different from angles and levels. They also monitor randomness, complex entities, uneven edges, and sudden leaps or sudden jumps" (Gleick \& Al-Shahhed, 2000). For example, Mr. X departed with his car with the possibility of a safe return. Thus, this will not be limited to his commitment to the teachings of traffic or his knowledge, but on several psychological and mental variables. This is in addition to the users of the road and their commitment to the teachings of traffic, weather, and other variables.

This also can be seen in the case of the stock market and the decisions related to it. So, "the most important of what is in the probability theory is its application on the random events. We refer to an event as a random event when it is characterized by the quality of "the impossibility of calculation", on one hand, and when we assume, on the other hand, that all the rational ways to predict it failed. We built this supposition on many useless attempts. We will have the feeling about this event, if you will, as we need a prophet, not a scientist to predict it. Based on this situation and the impossibility of the event calculation, we are deciding to apply the calculation of probability" (Popper 
\& Al-Baghdadi, 2006). Subsequently, it is not possible for a human to be able until he selects. This is because the selection is a form of an experiment that gives knowledge and ability which is directly proportional to knowledge. As knowledge increases, the ability increases, and the selection also increases with it. Furthermore, knowledge is always lacking and remains inevitable from a general subject. This means denying the absolute power of human and denying absolute science. At the same time, it urges human to constantly seek knowledge and to show the importance of education in achieving more choices and greater freedom (Figure 2).

\begin{tabular}{|l|l|}
\hline & Knowledge And Ability \\
\hline $\begin{array}{l}\text { Innate Knowledge } \\
\text { With Innate Ability }\end{array}$ & More Selection \\
\hline Source: The Author & Molection \\
\hline
\end{tabular}

Figure 2. Human begins with his innate knowledge and ability to Selects, Learn, and then to ability Increasing, knowledge, and Selection.

God represents eternal life that exists always. Hence, human ability is not in the amount of human default age. This can be seen by the cycle of life and death and their potentials which can be drawn from orbits such as the orbits that is calculated to determine the life of a long-lived tree that is compared to the default age of the butterfly. This gives another comprehensible, in knowledge. "The genetic material contained in 100 trillion cells which form the human body, if it outstretched, is equal to twenty times the distance between the earth and the sun" (Davies \& Al-Eiti, 2002). Human aims at survival, and its default age depends on many factors. Science is still discovering some and refuting some. The reason behind this default age is just a roof for his capabilities and not a roof for life. On the other hand, it is regarded as a roof for the possibility of his survival if natural balance is affected by any means, such as pollution. Furthermore, fish cannot exist outside the sea, not because there is no life in the mainland but because it will die. Also, any product that humans can produce, but cannot control, may form a real danger that will threaten his existence. Al-Mulk; "who created death and life that he might examine which of you is best indeed" (Shaykh et al., 2009). Death is a creature and it is case or conditions, but not "nothing". Also, life is a creature and it is a case, but not an "everything". The exam is an educational function, but to complete that function, there is a need for ethics material within the curriculum. Therefore, the importance of moral value is highlighted as the most important function of education. 


\section{Conclusion}

This present paper concludes that the importance of moral value is highlighted as the most important functions of education in Islam.

This is because is an essential part of the educational process for the purposes of faith so as to be ethically disciplined. So, it is important to know how to think before starting to think. This paper concludes that Islam help in setup to gain the confidence necessary for education and, at the same time, teaches responsibility. Also, the function of education in Islam depends on reward and punishment as a result of deeds; righteous deeds and unrighteous deeds.

Also, the philosophy of permissible and forbidden in Islam depends on the principle of what is harmful and what is not, whether on the personal level or the environment level. So, Islam takes into consideration organisms that participate human in nature. Therefore, this is in addition to other education functions such as repetition, orderliness, accomplishment, and manners of consumption. This paper concludes that Islam should require an electoral process for imam or teacher based on moral and scientific standards. It should also require an ethics material within the curriculum to make education outcomes within a framework to enhance the concept of belief in life, human, and the environment.

This present paper concludes that Islam, as a religion, encourages science and does not contradict it. The misunderstanding or misinterpretation of the Quran makes it vulnerable to deformation. At the same time, the scientific facts that humanity has discovered and proven are facts that encourage the ratification in the Quran as a call to faith. The Quran does not provide facts in the context of scientific or academic research but provides news in the form of questions that urge the mind to research and think.

Also, the successful application of Islam to science depends on the possibility of applying them together, as it not possible to separate the faith approach of the Quran and the scientific method in order to make a comparative work.

This is because the first approach propels the second approach. Consequently, the Quran description is accepting any scientific attempt to explain or prove the general description of a certain fact. Also, knowledge and religion (good) are not for consumption and if they are consumed, they turn into an ideology, and this happens only through commercial or political propaganda. This paper concludes that the search for knowledge is endless which urges humans to constantly seek knowledge, and it also shows the importance of education in achieving more choices and freedom.

This paper concludes on the importance of language in education as software that humans use naturally. It further emphasizes on the importance of vocabulary to be the most beautiful and more accurate, to be used as an 
educational language. In addition, the modern vocabulary that resulted from industrial revolutions should not be Arabized, but rather it should be used as called by its inventor. This paper concludes that there is a need for artificial intelligence to produce a machine that serves humans and should be done honestly. Also, the excessive use of technology affects education, as it stimulates senses more than thinking. This paper concludes that miracles occur upon a direct intervention of a capacity that is not possessed by a human. It is an event that comes to prove the truth of Quran or scripture because it outdoes the output of science at that time, even in the long run. Honesty is very important with the soul in the advancement of humans to a high level of ethics as well as knowledge. This paper concludes that knowledge is an interpretation, while visions are phenomenon influenced by environment, culture, scientific progress, and personal characteristics.

Also, interpretation of visions alongside with the vision as part of the prophet's prophecy does not apply to non-prophets. Thus, many people can have a vision but not all are honest, nor can all interpret it. So, the wrong interpretation of a phenomenon is the most dangerous part of it.

This paper defines logic as the expression of the object, its existence, its quality, and its interaction which received by thinker as a true result. Its acceptance depends on the innate and the laws (experience) in the thinker mind which is built by the process of thinking and receiving, which in turn gives the true result of thinking (intuition) and interpret the relationships, conditions, and results in a mathematical method known as mathematical logic.

Also, this paper concludes that the ideology as the apparent image of the real does not depend on substance. Its influence in the mind is stronger than the survival of the invisible substance. This helps in the understanding of the difference between madness and genius, which requires a special type of education.

This present paper concludes that instinct is a motive of necessity, whereas emotion is a motive of needs. In addition, emotion has the main effect of determinate aesthetics value. So, the word "faith" as a meaning of love also means acceptance. This present paper concludes that aesthetics appreciation is an important educational function, and the precious cultural and artistic legacy was one of its results. Also, this paper concludes that the literary value (behavior) or the material value represents an evaluation of aesthetics.

As the value maintains the aesthetics, then any missing of this value, in turn, leads to a kind of aesthetics consumption. This paper concludes that aesthetics appreciation is an essential function for artwork such as sculpture, engraving, drawing, and craftwork which were the most important components of the world's heritage. 


\section{References:}

1. Abdulhameed, S. (2005). Image Age (1 ${ }^{\text {st }}$ ED). Kuwait: National Council for Culture, Arts and Letters.

2. Al-Hashem, S. A. (1315 H). Jewels of Literature $\left(2^{\text {nd }}\right.$ ED). Beyrouth: Al-Maareff Est. Part (1,2).

3. Al-Mūsawi, M. (1989). from Alkindus to Averroes (4 $\left.{ }^{\mathrm{TH}} \mathrm{ED}\right)$. Beyrouth \& Paris: Editions Oueidat. Units (2).

4. Auzizs, J. M. \& Awa, A. (1983). La Philosophie Et Les Techniques $\left(2^{\text {nd }}\right.$ ED). Beyrouth \& Paris: Editions Oueidat.

5. Balibar, P. F. \& Addhum, S. (1993). Galilee, Newton Lus Par Einstein Espace Et relativite (1 ${ }^{\mathrm{ST}}$ ED). Beyrouth: University Corporation for Studies, Publishing and Distribution \& Presses Universitaires de France. Unit (6).

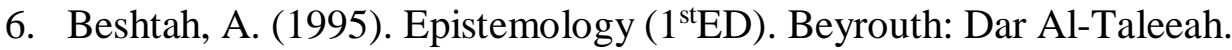

7. Brooks, R. A. \& Mohammad, M. (2004). Flesh and Machines: How Robots Will Change Us ( ${ }^{\text {st }}$ ED). New York \& Riyadh: Pantheon Book \& Obeikan Publishers.

8. Carpentier, R. \& Nasr, N. (1984). La Connaissance D’autrui (3 ${ }^{\mathrm{RD}}$ ED). Beyrouth \& Paris : Editions Oueidat.

9. Davies, K. \& Al-Eiti, Y. (2002). Cracking the Genome (1 ${ }^{\text {ST }}$ ED). New York \& Riyadh: The Free Press, a Division of Simon \& Schuster, Inc. \& Obeikan Publishers. Units (2).

10. Faụl Allāh, M. (1996). Descartes Philosophy and his Curriculum (3 ${ }^{\mathrm{RD}}$ ED). Beyrouth: Dar Al-Taleeah.

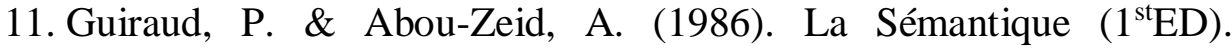
Beyrouth \& Paris: Editions Oueidat.

12. Gleick, J. \& Al-Shahhed, S. (2000). Chaos (1 $\left.{ }^{\mathrm{st}} \mathrm{ED}\right)$. Kuwait: Cultural Foundation Publication. Unit (2).

13. Greene, B., Mansoor, A. H., \& Shimon, N. (2005). Elegant Universe $\left(1^{\text {st } E D) . ~ K u w a i t ~ F o u n d a t i o n ~ f o r ~ t h e ~ A d v a n c e m e n t ~ o f ~ S c i e n c e . ~ U n i t s ~}\right.$ (2).

14. Harold, F. \& Al-Ayoubi, S. A. (2001). The Way of The Cell Molecules, Organisms, and the Order of Life ( $1^{\text {st } E D) . ~ O x f o r d ~}$ University Press, Inc \& Obeikan Publishers. Units (1).

15. Heisenberg, W. \& Al-smman, A. (1988). Physics and Philosophy: The Revolution in Modern Scince ( $2^{\text {nd }}$ ED). Beyrouth: Al-Resalah Est.

16. Jughaiman, A. O. (2019). A Philosophical Introduction of Islamic Political System and Social Behavior. European Scientific Journal, 104, 92, 96, 105, 89-108.

17. Knuth, D. E. (1997). The Art of Computer Programming ( ${ }^{\mathrm{RD}} \mathrm{ED}$ ). USA: Addison-Wesley. Volume (1), Unit (1). 
18. Kunzmann, P., Burkard, F. P., Wiedmann, F., Weib, A., \& Katorah, G. (1991). DTV-Atlas Philosophie ( $8^{\mathrm{TH}}$ ED). Beyrouth: East Library. Units (6).

19. Levy, S. \& Al-Mlah, A. (2002). Crypto (1 ${ }^{\text {ST }}$ ED). New York \& Riyadh: Viking Penguin, a Division of Penguin Putnam Inc. \& Obeikan Publishers.

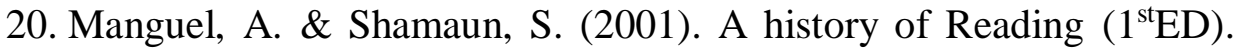
Canada \& Beyrouth: Alferd A. Knoph \& Dar Al Saqi.

21. Nettle, D. \& Al-Iobey, S. (2003). Strong Imagination: Madness, Creativity and Human Nature ( ${ }^{\mathrm{ST}}$ ED). Oxford University Press, Inc \& Obeikan Publishers.

22. Pfenninger, K. H., ShuBik, V. R., \& Bahboh, M. H. (2003). The Origins of Creativity ( $1^{\mathrm{ST}}$ ED). Oxford University Press, Inc \& Obeikan Publishers. Units (3).

23. Polkinghorne, J. \& Ali, A. Y. (1998). Beyond Science ( ${ }^{\text {st ED). }}$ National Project for Translation. Unit (8).

24. Popper, K. \& Al-Baghdadi, M. (2006). Logik Der Forschung ( $1^{\text {ST }}$ ED). Beyrouth: Arab Organization for Translation. Unit (8).

25. Shaykh, G., Shaykh, H. Q., Darwish, A. (2009). The holy Quran translation: Al-Mulk, Al-Esra, Al-Nahl, Ar-Rum, Fatir, Al-Jumu' ah, Lugman, Al-Hajj, Ta-Ha, An-Naml, Al-Anbiya, Yusuf, Al-Furqan, Al-Ma’idah, Al-Jinn, Al-Baqarah, As-Saff, Adh-Dhariyat, Ya-Sin, AtTalaq, As-Saffat, Al-Alaq.

26. http://www.e-quran.com/language/english/english4/default.html

27. Spielberg, N., Anderson, B. D., \& Johur, M. A. (2002). Seven Ideas that Shook the Universe $\left(1^{\mathrm{ST}}\right.$ ED). Kuwait Foundation for the Advancement of Science. Units (1).

28. Squire, L., Kandel, E., \& Arar, S. (2002). Memory from Mind to Moleculs ( $1^{\text {ST }}$ ED). Publishers New York \& Riyadh: W.H. Freeman and Company, Basingstocke \& Obeikan.

29. Tersine, R. J. (1988). Principles of Inventory and Materials Management ( $3^{\mathrm{RD}}$ ED). New York: Elsevier Science Publishing Co., Inc. Units (9).

30. Tromba, A., Hildebrabdt, S., Al-Ahmad, K., \& al-Hamawy, A. (2000). Mathematics and Optimal Form ( $1^{\text {st }}$ ED). Kuwait Foundation for the Advancement of Science.

31. Quine, W. (1996). Elementary logic ( ${ }^{\text {st }}$ ED). Beirut: Dar Al-Talyaah Publications \& presses. 